\title{
Nickel-Catalyzed Cycloadditions of Unsaturated Hydrocarbons, Aldehydes, and Ketones
}

\author{
Thomas N. Tekavec and Janis Louie \\ Department of Chemistry, University of Utah, 315 South 1400 East, Salt Lake City, Utah \\ 84112-0850
}

Janis Louie: louie@chem.utah.edu

\section{Abstract}

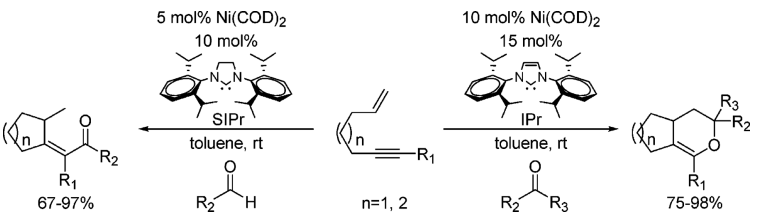

\begin{abstract}
The nickel-catalyzed cycloaddition of unsaturated hydrocarbons and carbonyls is reported. Diynes and enynes were used as coupling partners. Carbonyl substrates include both aldehdyes and ketones. Reactions of diynes and aldehydes afforded the [3,3] electrocyclic ring-opened tautomers, rather than pyrans, in high yields. The cycloaddition reaction of enynes and aldehydes afforded two distinct products. A new carbon-carbon bond is formed, prior to a competitive $\beta$ hydrogen elimination of a nickel alkoxide, between the carbonyl carbon and either one of the carbons of the olefin or the alkyne. The steric hindrance of the enyne greatly affected the chemoselectivity of the cycloaddition of enynes and aldehydes. In some cases, dihydropyran was also formed. The scope of the cycloaddition reaction was expanded to include the coupling of enynes and ketones. No $\beta$-hydrogen elimination was observed in cycloaddition reaction of enynes and ketones. Instead, $\mathrm{C}-\mathrm{O}$ bond-forming reductive elimination occurred exclusively to afford dihydropyrans in excellent yields. In all cases, complete chemoselectivity was observed; only dihydropyrans where the carbonyl carbon forms a carbon-carbon bond with a carbon of the olefin, rather than of the alkyne, were observed. All cycloaddition reactions occur at room temperature and employ nickel catalysts bearing the hindered 1,3-bis(2,6-diisopropylphenyl)imidazol-2ylidene (IPr) or its saturated analogue, 1,3-bis(2,6-diisopropylphenyl)-4,5-dihydroimidazolin-2ylidene (SIPr).
\end{abstract}

\section{Introduction}

Transition metal-catalyzed [ $2+2+2]$ cycloadditions are an extremely powerful method for the synthesis of various carbo- and heterocyclic compounds. ${ }^{1}$ Not only are the reactions

(C) 2008 American Chemical Society Published

Correspondence to: Janis Louie, louie@chem. utah. edu.

Supporting Information Available: Full Experimental Section, including characterization of all reaction products and demonstration of purity. This material is available free of charge via the Internet at http://pubs.acs.org. 
carried out catalytically under neutral conditions, but they offer a great degree of flexibility in the compounds that can be synthesized. For instance, one diyne can be transformed into a benzene ring, pyridone, pyridine, pyrone, or pyran depending on whether it is coupled with alkyne, isocyanate, nitrile, carbon dioxide, or a carbonyl (aldehydes and ketones) (Scheme 1). ${ }^{2}$ While a great degree of success has been realized with $[2+2+2]$ cycloadditions of diynes with alkynes, ${ }^{3}$ isocyanates,${ }^{4}$ nitriles,${ }^{5}$ and carbon dioxide, ${ }^{6}$ far less success has been had with aldehydes ${ }^{7}$ and ketones. ${ }^{8,9}$ The inability to efficiently couple carbonyls with diynes via a transition metal-catalyzed $[2+2+2]$ cycloaddition is unfortunate due the prevalence of pyrans in several biologically important compounds. Thus a direct, catalytic cycloaddition route utilizing simple starting materials conducted under neutral reaction conditions would be a valuable synthetic tool in the construction of pyrans.

The relative lack of success in the coupling of carbonyls and diynes can be attributed to a combination of two factors. The first is the increased steric bulk of carbonyls relative to alkynes, isocyanates, nitriles, and carbon dioxide. The latter all possess sp-hybridized carbons whereas carbonyl carbons are $\mathrm{sp}^{2}$-hybridized. Such a simple change in hybridization severely limits the "faces" from which an electrophile can be attacked from. The linear molecules (those containing sp-hybridized carbons) can easily be attacked from any face in their $360^{\circ}$ radius. Trigonal planar molecules (those containing $\mathrm{sp}^{2}$-hybridized carbons) can only be easily attacked from one of two faces (i.e., the top face or the bottom face).

The second contributing factor is the energetically demanding $\mathrm{C}-\mathrm{O}$ bond-forming reductive elimination required for the pyran formation. Indeed, the reductive elimination of ethers from transition metal complexes is a rare elementary reaction that is generally limited to special cases. Of particular note are processes catalyzed by Pd phosphine systems that afford aryl ethers via key $\mathrm{C}-\mathrm{O}$ reductive-elimination steps. ${ }^{10}$ Such systems typically employ sterically hindered alkylphosphine or bidentate arylphosphines. The efficacy of these ligands is believed to lie in their ability to inhibit facile $\beta$-hydrogen elimination from the alkoxide intermediate ${ }^{11}$ and to accelerate rate-determining $\mathrm{C}-\mathrm{O}$ bond-forming reductive elimination. Similar reductive eliminations from $\mathrm{Ni}$ complexes appear to be more challenging. Theoretical calculations have shown that in $\mathrm{C}-\mathrm{X}$ bond-forming reductive eliminations from $\left(\mathrm{PH}_{3}\right)_{2} \mathrm{Ni}\left(\mathrm{CH}_{3}\right)(\mathrm{X})$ complexes (where $\mathrm{X}=\mathrm{C}, \mathrm{O}$, or $\mathrm{N}$ ), the $\mathrm{C}-\mathrm{O}$ reductive elimination is 6.0 $\mathrm{kcal} / \mathrm{mol}$ higher than the $\mathrm{C}-\mathrm{N}$ reductive elimination and $19.1 \mathrm{kcal} / \mathrm{mol}$ higher than the $\mathrm{C}-\mathrm{C}$ reductive elimination. ${ }^{12}$ In fact, Hillhouse demonstrated $\mathrm{Ni}$ (II) alkoxide complexes require oxidation to induce $\mathrm{C}-\mathrm{O}$ reductive elimination through a one-electron process. In contrast, thermolysis of the Ni complexes favors $\beta$-hydrogen elimination of the alkoxide ligand followed by $\mathrm{C}-\mathrm{H}$ reductive elimination. ${ }^{13}$

In accordance with these difficulties, only two examples of transition metal catalyzed [ $2+2$ +2 ] cycloadditions of diynes with carbonyls have been reported (Scheme 2). Both reactions require elevated temperatures and relatively reactive carbonyl substrates (i.e., aldehydes and activated ketones). The first was by Tsuda and co-workers who successfully coupled diynes with aldehydes in the presence of a Ni/phosphine catalyst to generate a pyran. ${ }^{7 \mathrm{a}}$ The second was by Itoh and co-workers who used a Ru catalyst to couple diynes with a tricarbonyl to afford a dieneone, which is the $\mathrm{e}^{3,3}$ electrocyclic ring-opened tautomer of the pyran cycloadduct. $^{8}$ 
Previous results from our laboratory have shown that Ni/NHC $(\mathrm{NHC}=\mathrm{N}$-heterocyclic carbene) complexes efficiently catalyze the $[2+2+2]$ cycloaddition of diynes with isocyanates, nitriles, and carbon dioxide. ${ }^{4 b, 5 e, 6 c, d}$ On the basis of these results and the limited success in the coupling of diynes with carbonyls, we sought to expand our Ni/NHC catalyst system to include the coupling of carbonyls with diynes. Herein, we report the development of a $\mathrm{Ni} / \mathrm{NHC}$ catalyst that effectively cyclizes unsaturated hydrocarbons, such as diynes and enynes, with carbonyl substrates, such as aldehydes and ketones, at ambient temperature.

\section{Results and Discussion}

\section{Cycloaddition of Diynes and Aldehydes: Catalyst Development}

A variety of conditions were evaluated by using diyne $\mathbf{1}$ and benzaldehyde as model substrates for the cycloaddition reaction (eq 1). Initially, several phosphines and carbenes were screened as potential ligands for this reaction (Table 1). Since Tsuda and Saegusa's original report, several new bulky phosphine ligands, which have shown improved reactivity in $\mathrm{C}-\mathrm{N}$ and $\mathrm{C}-\mathrm{O}$ bond-forming cross-couplings, ${ }^{14}$ have been developed and were included in our ligand screen. Unfortunately, no diyne conversion was observed with any of the phosphine ligands (entries 2-7). Upon switching to the N-heterocyclic carbene ligands, ${ }^{15}$ which we have successfully employed in other cycloaddition reactions,, b, $5 \mathrm{e}, 6 \mathrm{c}-\mathrm{d}, 16$ improved conversions and yields were observed. High diyne conversion was observed when a sterically hindered $N$-alkyl carbene was employed; however, only trace amounts of the desired pyran were observed (entry 8). When $N$-aryl carbenes were employed, a marked increase in the ratio of pyran formation to diyne conversion was observed (entries 9-11). The highest yields of pyran were observed with $N$-aryl carbenes possessing increased steric hindrance (entries 10-11). Interestingly, the saturated SIPr ligand provided significantly higher conversions of diyne in conjunction with higher pyran yields than reaction run in the presence of the sterically similar IPr ligand.

Ultimately, a protocol similar to the one found effective for the cycloaddition of alkynes and $\mathrm{CO}_{2}{ }^{6 \mathrm{c}, \mathrm{d}}$ cleanly afforded dienone 2 , which is derived from electrolytic ring opening of the initially formed pyran $\mathbf{2}^{\prime}$ (eq 2). ${ }^{17}$ Excellent yields (as determined using gas chromatography) were obtained with $5 \mathrm{~mol} \%$ of $\mathrm{Ni}(\mathrm{COD})_{2}, 10 \mathrm{~mol} \%$ of SIPr, a diyne concentration of $0.1 \mathrm{M}$ in toluene, and a slight excess (1.25 equiv) of aldehyde at room temperature. 

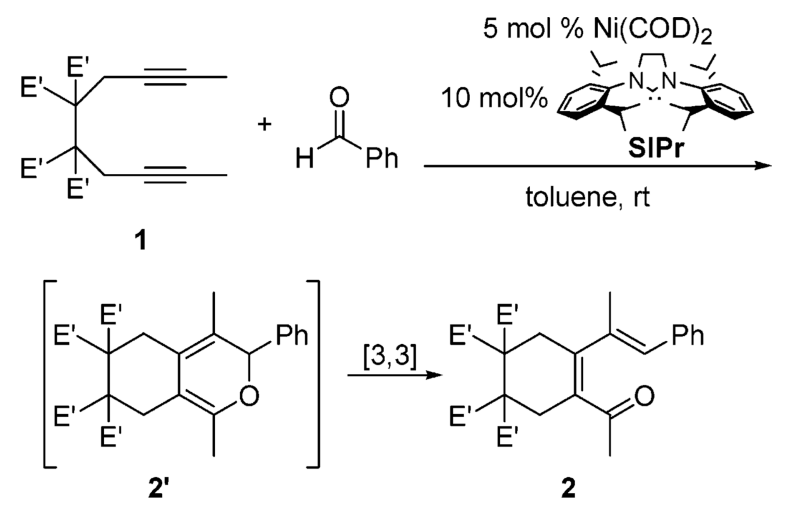

\section{Cycloaddition of Diynes and Aldehydes: Formation of Dienones ${ }^{18}$}

As illustrated in Table 2, the Ni/SIPr combination catalyzes the cycloaddition reaction of diynes and various aldehydes. For example, benzaldehyde cyclized smoothly at room temperature with diynes $\mathbf{1}$ and $\mathbf{7}$ to afford dienones $\mathbf{2}$ and $\mathbf{8}$ in good yields (entries 1 and 6 , respectively). The cycloaddition of an aryl aldehyde bearing an electron-donating group ( $p$ $\mathrm{OMe}$ ) afforded the dienone product in a higher yield than the reaction of an aryl aldehyde possessing an electron-withdrawing group ( $\left.p-\mathrm{CF}_{3}\right)$ (entries 2 and 3, respectively). Aliphatic aldehydes also underwent facile cycloaddition (entries 4 and 5) with slightly modified conditions $\left(10 \mathrm{~mol} \% \mathrm{Ni}(\mathrm{COD})_{2}\right.$ and $\left.10 \mathrm{~mol} \% \mathrm{SIPr}\right)$. In addition, excess butyraldehyde (entry 5, 5 equiv) was necessary to ensure complete dienone forma-tion. ${ }^{19}$

Diynes possessing a three-carbon linkage between alkynes also underwent Ni-catalyzed cyclization with aldehydes. When diynes 9 and $\mathbf{1 1}$ were subjected to benzaldehyde under standard cyclization procedures, dieneones $\mathbf{1 0}$ and $\mathbf{1 2}$ were obtained in $20 \%$ and $91 \%$ yield, respectively (eqs 3 and 4). Interestingly, the connectivity of dienones $\mathbf{1 0}$ and $\mathbf{1 2}$ was different than those obtained from reactions involving diynes possessing a four-carbon linkage (Table 2). Specifically, the $\mathrm{C}-\mathrm{C}$ bond between the carbonyl carbon and the $\mathrm{Ph}$ group of benzaldehyde is cleaved in dienones 2-8 (Table 2). In contrast, this bond remains connected in dienones $\mathbf{1 0}$ and 12. A similar outcome occurs in Ni/PR3-catalyzed cycloadditions where reactions were run at high temperatures. ${ }^{7 \mathrm{a}}$ It is believed that products of this nature arise from a $[1,5] \mathrm{H}$ shift. ${ }^{7 \mathrm{a}}$ An alternative account of these products involves $\beta$-hydrogen elimination from a Ni alkoxide intermediate $(\mathbf{1 3}$, Scheme 3$) .{ }^{13}$ If nickelacycle 13 undergoes $\mathrm{C}-\mathrm{O}$ bond-forming reductive elimination, dienones where the carbonylcarbon bond has been cleaved are formed. On the other hand, if nickelacycle $\mathbf{1 3}$ undergoes $\beta$-hydrogen elimination and subsequent carbon-hydrogen reductive elimination, dienones where the carbonyl-carbon bond remains intact are formed. The ratio of products would therefore depend on the relative rates of carbon-oxygen bond-forming reductive elimination and $\beta$-hydrogen elimination. It is likely that carbon- oxygen bond-forming reductive elimination is more facile when a less strained $[6,6]$ ring system is being formed (i.e., when $n=2$ ), which explains the formation of electrocyclic ring-opened cycloadducts $(\mathbf{2}-\mathbf{8})$. In contrast, the higher energy barrier to form a relatively strained [5,6] ring system (i.e., when 
$n=1$ ) prevents carbon-oxygen bond-forming reductive elimination from occurring, and in turn, only dienone products arising from $\beta$-hydride elimination are observed (e.g., dienones 10 and 12).
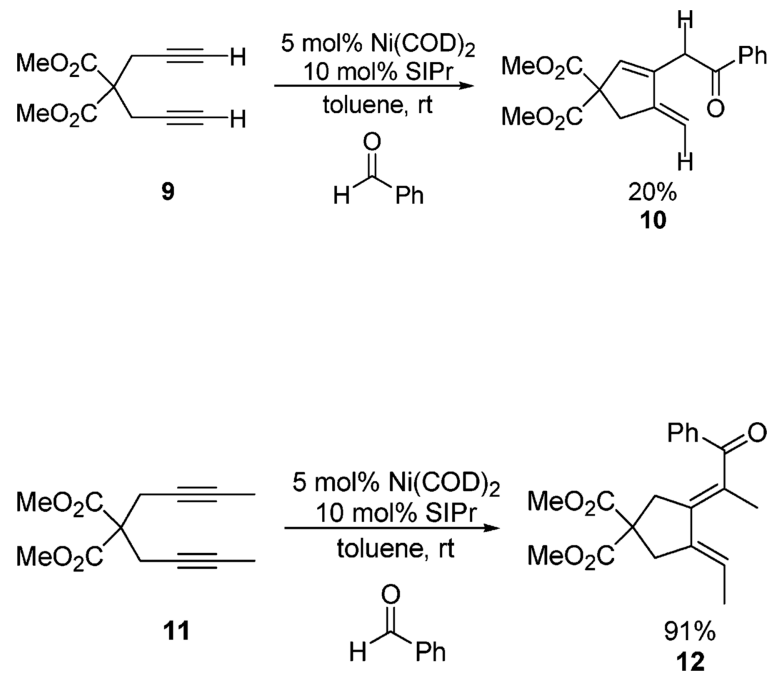

\section{Cycloaddition of Enynes and Aldehydes}

The cycloaddition of enynes and carbonyls (or even heterocumulene derivatives) 20,21 $^{2}$ remains a challenge in synthetic chemistry. Given the dramatic increase in reactivity of the $\mathrm{Ni}$-carbene catalysts in the cycloaddition of diynes and aldehydes, enynes were evaluated as potential substrates. Thus, enyne 14 was subjected to benzaldehyde under optimized reaction conditions at room temperature (eq 5). Cyclization led to the formation of two products, enone $\mathbf{1 5}$ and ketone 16, which were isolated in a 1:1.6 ratio for a combined overall yield of $79 \%$. The carbonyl carbon of the aldehyde substrate is connected to the alkyne portion in enone $\mathbf{1 5}$ whereas this carbon is connected to the alkene portion in ketone $\mathbf{1 6 .}$

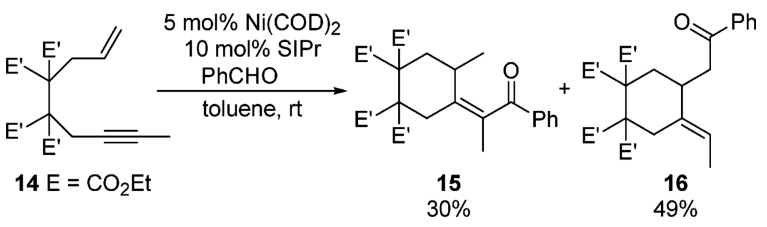




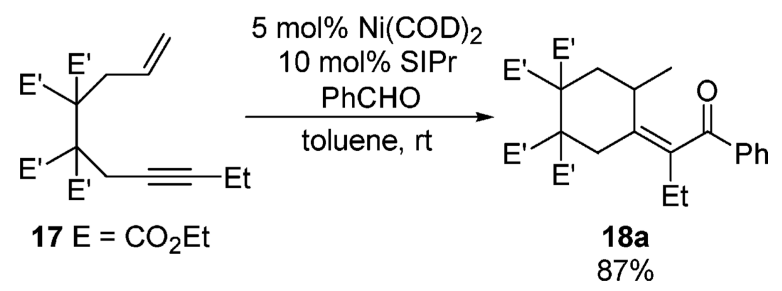

The cycloaddition reaction of benzaldehyde and enyne 17, whose sole difference from enyne 14 is an ethyl substituent on the terminal end of the alkyne, gave enone 18a exclusively under identical reaction conditions (eq 6 and entry 1 of Table 3). Thus, when enynes with slightly larger alkynes were used as the substrates, only enone products were obtained (Table 3). In all cases, products arising from the addition of the carbonyl carbon to the alkene were not observed. Furthermore, addition of the carbonyl carbon to the alkyne was observed regardless of the aldehyde substrate. For example, both aryl and alkyl aldehydes produced enone products (entries 1-6, Table 3). Increasing the steric hindrance of the aldehyde had no effect on the chemoselectivity of the reaction (entries 2 and 5). Electrondonating and electron-withdrawing aryl aldehydes both afforded enone products suggesting electronic effects of the aldehyde do not play a major role in determining the chemoselectivity between enone and ketone formation (as seen in Table 3). The cycloaddition also proceeded smoothly in the presence of silyl and benzyl protecting groups to give the corresponding enones in good to excellent yield (entries 7 and 8). Enynes with a three-carbon linkage also cyclized to afford the enone product as a five-membered carbocycle (entry 9).

\section{Chemoselectivity of the Cycloaddition of Substituted Enynes: Alkyne Substituents}

The difference in product ratio (enone:ketone) obtained in the cycloaddition of enyne $\mathbf{1 4}$ versus enyne 17 suggested the chemoselectivity could be influenced by varying the steric bulk of the alkyne substituent. Thus, a series of substituted enynes, containing one terminal olefin and an internal alkyne bearing a terminal group of varying size $(\mathrm{R}=\mathrm{H}, \mathrm{Me}, \mathrm{Et}, i-\mathrm{Pr}$, and $n$-Pr), were prepared. These enynes $(14,17,25,27,29)$ were subjected to benzaldehyde under the standard cycloaddition conditions (Table 4). When the R group at the terminal position of the alkyne was a hydrogen atom (entry 1), only ketone $\mathbf{2 6}$, arising from the addition of the aldehyde to the olefin, was observed. Increasing the size of the R group to methyl led to the formation of both enone (15) and ketone (16) products in relatively equal amounts (1:1.6). When the alkyne substituent was Et (entry 3) or larger (entries 4 and 5), a complete reversal in product formation was observed. In these cases, the carbonyl carbon preferentially reacted with the alkyne portion of the enyne.

\section{Chemoselectivity of the Cycloaddition of Substituted Enynes: Olefin Substituents}

The effect of olefin substitution on the chemoselectivity was also investigated. When the alkyne bears a methyl group at its terminus, a mixture of enone and ketone products were obtained (entry 2, Table 4). This feature suggested that enynes of this nature (i.e., $R=M e$ ), 
but bearing various substituted tethered olefins, would allow us to delineate the effect of olefin substitution on the chemoselectivity of the cycloaddition. Thus, a series of enynes (31, 32, and 35) bearing methyl substitution on the olefin were prepared and subjected to benzaldehyde under standard cycloaddition conditions. Enyne $\mathbf{3 1}$ that possesses a transsubstituted olefin failed to react (eq 7), which may be due to a decreased ability of the olefin to bind to the metal center. On the other hand, the analogous cis enyne $\mathbf{3 2}$ cyclized with benzaldehyde to yield ketone 33 and pyran 34 (eq 8). Likewise, the cyclization of enyne 35 with benzaldehyde produced similar results. Ketone 36 and pyran $37^{22}$ were formed in $82 \%$ and $18 \%$, respectively (eq 9). In all cases, only products arising from the coupling of the carbonyl carbon with the olefin were obtained.

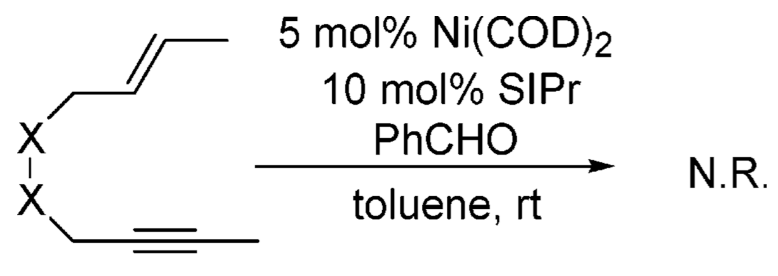

\section{$31 \mathrm{X}=\mathrm{C}\left(\mathrm{CO}_{2} \mathrm{Et}\right)_{2}$}
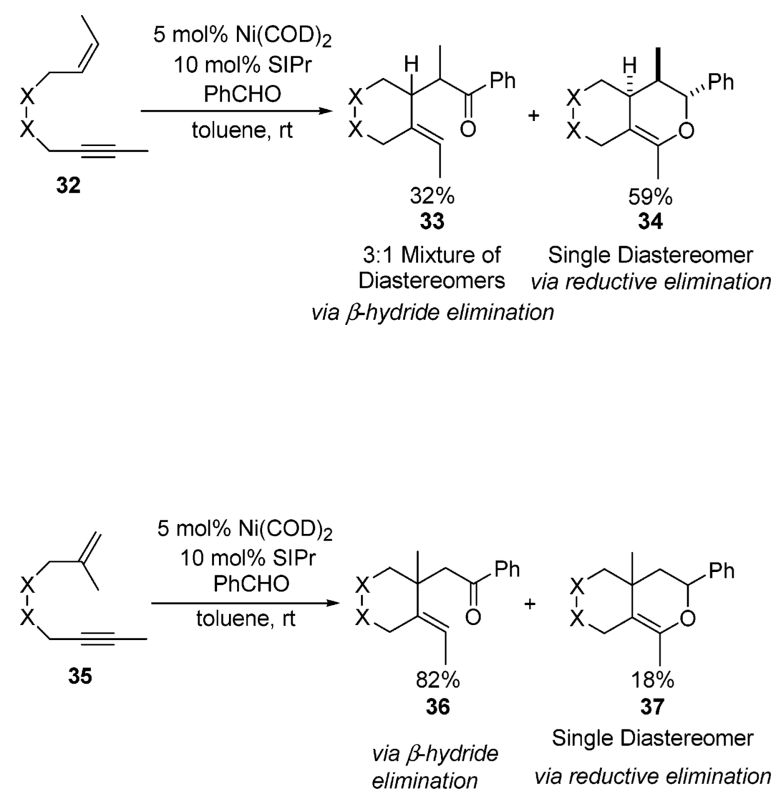

Interestingly, although ketone $\mathbf{3 3}$ was obtained as a mixture of diastereomers, formation of the pyran products displayed higher selectivity. Both pyrans 34 and 37 were isolated as single diastereomers (eqs 8 and 9). The trans configuration between the methyl and phenyl substituents was confirmed by X-ray analysis. ${ }^{23}$ 


\section{Rationale for the Chemoselectivity of the Cycloaddition of Enynes and Aldehydes}

The chemoselectivity observed in these cycloaddition reactions may be due to a similar rational for the selectivity observed in cycloadditions between diynes with $\mathrm{CO}_{2},{ }^{6 \mathrm{c}, \mathrm{d}}$ isocyanates, ${ }^{4 \mathrm{~b}}$ and nitriles. ${ }^{5 \mathrm{~b}}$ In those reactions, unsymmetrical diynes that possess a large TMS (or $t$-Bu) group on one of the alkynyl units undergo regioselective cycloaddition. The regioselectivity is most likely governed by an insertion step. Thus, to minimize steric repulsion between the TMS group and the sterically hindered NHC ligand, heterocyclic products that bear the TMS group in the 3-position are formed. Similarly, the chemoselectivity observed in the cycloaddition of enynes and aldehydes may be dictated by the insertion step (Scheme 4) ${ }^{24-26}$ Increasing the steric hindrance of the alkyne substituent (R) favors coupling between the alkyne and the aldehyde through the preferential formation of oxanickelacycle 38. This intermediate minimizes the steric repulsion between the alkyne substituent and the NHC ligand. Similarly, enynes bearing methyl substitution on the olefin lead to increased coupling between the olefin and the aldehyde through the selective formation of oxanickelacycle 39. This intermediate minimizes the steric repulsion between the olefin substituent (i.e., a methyl) and the NHC ligand. For both 38 and 39, facile $\beta-\mathrm{H}$ elimination from the alkoxide ligand occurs to afford the carbonyl products. Interestingly, substitution on the olefin appears to enhance $\mathrm{C}-\mathrm{O}$ bond-forming reductive elimination ${ }^{24}$ as pyran products are observed (eqs 8 and 9).

\section{Cycloaddition of Enynes and Ketones}

Given the facile nature of the cycloaddition between enynes and aldehydes, other carbonyl substrates were examined in an effort to further expand the scope of the reaction. Thus, ketones were used as coupling partners in lieu of aldehydes. Not only would this exchange open a relatively unexplored realm in $[2+2+2]$ cycloadditions, but the use of ketones would also eliminate the possibility of the $\beta$-hydrogen elimination that occurs when aldehydes are used. At the onset, it was unclear whether ketones would be suitable substrates for the cycloaddition. As seen with cycload-ditions involving $\mathrm{CO}_{2}$ or aldehydes, the $\mathrm{Ni} /$ carbene-catalyzed cycloadditions are sensitive to steric hindrance. Thus, it was possible that ketones may be too sterically hindered to undergo cyclization. Another concern was that simple alkyl ketones may not have sufficient electrophilicity to undergo oxidative coupling or insertion into a nickelacycle intermediate. ${ }^{24 d, 27}$ Indeed, Rucatalyzed cyclizations of diynes and ketones only provide products when electron-deficient ketones were employed. ${ }^{8}$

Initially, the cycloaddition of a ketone, cyclohexanone, and a diyne (1) was evaluated (eq 10). Gratifingly, cyclohexanone reacted smoothly with diyne 1 under slightly modified conditions to afford pyran $\mathbf{4 0 a}$ in $80 \%$ yield. As observed in the reaction of diynes and aldehydes, pyran 40a also underwent spontaneous electrolytic ring opening. However, in this case, the pyran (40a) existed in thermal equilibrium with its ring-opened dienone tautomer $\mathbf{4 0 b}$ in a ratio of 10:1. 

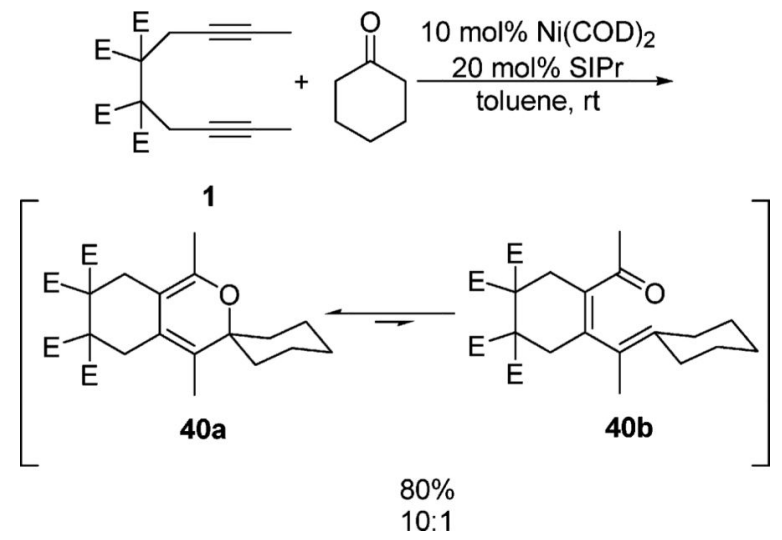

The cycloaddition of ketones was then evaluated with enynes. Enyne 14 and acetone were subjected to standard reaction conditions and dihydropyran 41 was obtained, albeit in low yield. However, the yield of dihydropyran could be increased by the slow addition of the enyne to the reaction mixture. Ultimately, the slow addition of enyne $\mathbf{1 4}$ at room temperature to a stirring solution of $\mathrm{Ni}(\mathrm{COD})_{2}(10 \mathrm{~mol} \%), \operatorname{IPr}(15 \mathrm{~mol} \%)$, and acetone (1.25 equiv) in toluene afforded dihydropyran $\mathbf{4 1}$ as a single regioisomer in good isolated yield (Table 5). To our knowledge, this is the first example in which both anunactivated ketone and enyne participate in a cycloaddition reaction.

Further optimization of the reaction conditions showed that the addition of $3 \AA$ molecular sieves $(150 \mathrm{mg} / \mathrm{mmol})$ led to improved yields. ${ }^{28}$ With use of these conditions, a variety of unactivated ketones cyclized to afford pyrans in excellent yields (>91\%). As illustrated in Table 5, steric hindrance about the carbonyl played a large role in determining the reaction conditions. Both the ketone concentration and enyne addition time needed to be adjusted accordingly to minimize oligomeric side products. For instance, 1.25 equiv of acetone smoothly reacted with enyne $\mathbf{1 4}$ by adding the enyne over $0.5 \mathrm{~h}$ (entry 1 ). However, when 3 pentanone was used (entry 2), 4.0 equiv of ketone and an enyne addition time of $4 \mathrm{~h}$ was needed to obtain a comparable yield. Unsymmetrical methyl ketones also produced the cycloadducts in excellent yields (entries 3 and 4). Cyclic ketones possessing 5-, 6-, and 7carbon rings were also suitable substrates for the reaction requiring 1.25-4 equiv of ketone and enyne addition times of $0.5-2 \mathrm{~h}$ (entries 5-7).

As shown in Table 6, enynes with variable substitution patterns and functionality were also tolerated. Enyne 35 (entry 1), possessing a methyl group at the internal position of the olefin, smoothly cyclized to yield pyran $\mathbf{4 8}$ as a single diastereomer as confirmed by X-ray analysis. ${ }^{23}$ However, placing substituents at the terminal position of the olefin proved more problematic. While an internal olefin with cis geometry required 10 equiv of acetone to obtain a high yield of the dihydropyran (entry 2), internal olefins with a trans geometry failed to produce any of the desired product. On the other hand, increasing substituent length on the alkyne had little effect on the reaction (entry 3). A fused [5,6] ring system was obtained from the cyclization of enyne $\mathbf{5 1}$ (entry 4), although a slightly higher amount of 
acetone was required. Enynes containing functionalities such as ethers (entry 5) and amines (entry 6) also cyclized proficiently.

\section{Rationale for the Chemoselectivity of the Cycloaddition of Enynes and Ketones}

In contrast to the cycloaddition of aldehydes and enynes, substitution on either the olefin or the alkyne terminus had little effect on the chemoselectivity of pyran formation. In all cases, the carbonyl carbon was bound to the olefin, regardless of the alkyne substituent. For example, enyne $\mathbf{1 7}$ that has an ethyl terminus still provided pyran $\mathbf{5 0}$ (Table 6, entry 3). Despite this difference, it is likely the cycloadditions of carbonyls (i.e., ketones and aldehydes) and enynes have similar mechanisms. As such, mechanisms A and B (Schemes 4 and 5) can be used to rationalize the chemoselectivity observed in the formation of all the pyrans $(\mathbf{4 8 - 5 0 , 5 2 , 5 4 , 5 6 , 5 8})$. However, in this case, the ability to undergo $\mathrm{C}-\mathrm{O}$ bondforming reductive elimination governs the chemoselectivity. Reversible oxidative coupling (to form an oxanickelacyclopentane $\mathrm{e}^{24,25,26}$ or a nickelacyclopentene ${ }^{29}$ ) and insertion steps $\mathrm{s}^{30}$ lead to the formation of oxanickelacycloheptene intermediates $\mathbf{3 8}$ and $\mathbf{3 9}$ (Schemes 4 and 5). However, only complex $\mathbf{3 9}$ is likely to undergo $\mathrm{C}-\mathrm{O}$ bond-forming reductive elimination. Carbon-oxygen bond-forming reductive elimination from complex $\mathbf{3 8}$ would require the formation of $\mathrm{a}_{\mathrm{sp} 3}-\mathrm{O}$ bond, which has only been observed under oxidative conditions. ${ }^{13}$ Thus, regardless of the size of the substituent, oxidative coupling and insertion events may be reversible thereby allowing all the components to rearrange and form complex $\mathbf{3 9}$ and, ultimately, pyran $\mathbf{3 9 b}$ rather than $\mathbf{3 8 b}$ (Scheme 5).

\section{Conclusion}

It was found that diynes can undergo a [2+2+2] cycloaddition with aldehydes in the presence of a $\mathrm{Ni} /$ carbene catalyst. While dienones were obtained for the cyclization of 1,6and 1,7-diynes, their connectivity was different. It is believed that in the cyclization of 1,6diynes, the dienone arises from a $\beta$-hydrogen elimination/C-H reductive elimination. In the case of 1,7-diynes, the observed dienone arises from a $\mathrm{C}-\mathrm{O}$ reductive elimination/ electrocyclic ring-opening sequence. This methodology was expanded to include enynes as substrates to generate ketones, enones, or pyrans. Evidence suggests that the chemoselectivity of the reaction is governed by steric hindrance about the enyne, with the aldehyde reacting preferentially with the more sterically hindered unsaturated hydrocarbon. Finally, it was found that pyrans can be obtained chemoselectively in excellent yields from the cyclization of enynes and ketones. This represents the first successful attempt at using enynes and ketones as coupling partners in a $[2+2+2]$ cycloaddition reaction.

\section{Experimental Procedures}

\section{General Procedure for the Cycloaddition of Diynes and Aldehydes}

In a glovebox, a solution of diyne $(0.39 \mathrm{mmol})$ and aldehyde $(0.49 \mathrm{mmol})$ in $3 \mathrm{~mL}$ of toluene was added to an oven-dried scintillation vial equipped with a magnetic stir bar. To the stirring solution, a solution of $\mathrm{Ni}(\mathrm{COD})_{2}(5.4 \mathrm{mg}, 0.020 \mathrm{mmol})$ and $\mathrm{SIPr}(15.3 \mathrm{mg}, 0.039$ $\mathrm{mmol}$ ) in $0.9 \mathrm{~mL}$ of toluene, which was previously equilibrated for at least $6 \mathrm{~h}$, was added. The reaction mixture was stirred at room temperature for $2 \mathrm{~h}$ (or until complete consumption 
of starting material was observed as judged by GC or TLC) over which time the color changed from orange to brown. Upon consumption of the diyne, the mixture was concentrated in vacuo. The residue was purified by column chromatography on silica gel. The reaction conditions and results are shown in Table 2.

\section{General Procedure for the Cycloaddition of Enynes and Aldehydes}

In a glovebox, a solution of diyne $(0.32 \mathrm{mmol})$ and aldehyde $(0.40 \mathrm{mmol})$ in $3 \mathrm{~mL}$ of toluene was added to an oven-dried scintillation vial equipped with a magnetic stir bar. To the stirring solution was added a solution of $\mathrm{Ni}(\mathrm{COD})_{2}(4.4 \mathrm{mg}, 0.016 \mathrm{mmol})$ and $\operatorname{SIPr}(12.5$ $\mathrm{mg}, 0.032 \mathrm{mmol}$ ) in $0.2 \mathrm{~mL}$ of toluene, which was previously equilibrated for at least $6 \mathrm{~h}$. The reaction mixture was stirred at room temperature for $2 \mathrm{~h}$ (or until complete consumption of starting material was observed as judged by GC or TLC) over which time the color changed from orange to brown. Upon consumption of the enyne, the mixture was concentrated in vacuo. The residue was purified by column chromatography on silica gel. The reaction conditions and results are shown in Table 3 and Table 4.

\section{General Procedure for the Cycloaddition of Enynes and Ketones}

In a glovebox, a solution of diyne $(0.37 \mathrm{mmol})$ and aldehyde $(0.46 \mathrm{mmol})$ in $3 \mathrm{~mL}$ of toluene was added to an oven-dried scintillation vial equipped with a magnetic stir bar. To the stirring solution was added a solution of $\mathrm{Ni}(\mathrm{COD})_{2}(10.0 \mathrm{mg}, 0.037 \mathrm{mmol})$ and $\operatorname{IPr}(15.3$ $\mathrm{mg}, 0.055 \mathrm{mmol}$ ) in $0.6 \mathrm{~mL}$ of toluene, which was previously equilibrated for at least $6 \mathrm{~h}$. The reaction mixture was stirred at room temperature for $2 \mathrm{~h}$ (or until complete consumption of starting material was observed as judged by GC or TLC) over which time the color changed from orange to brown. Upon consumption of the enyne, the mixture was concentrated in vacuo. The residue was purified by column chromatography on silica gel. The reaction conditions and results are shown in Table 5 and Table 6.

\section{Supplementary Material}

Refer to Web version on PubMed Central for supplementary material.

\section{Acknowledgments}

The authors thank Matt Snyder for the synthesis of some of the NHC ligands used in this study. We also thank Atta M. Arif for obtaining the X-ray crystallographic data. We gratefully acknowledge Merck, NSF (Career Award), the NIH-NIGMS, and the Alfred P. Sloan Foundation for supporting this research.

\section{References}

1. Review: Chopade PR, Louie J. Adv. Synth. Catal. 2006; 348:2307.

2. (a) Schore, NE. Comprehensive Organic Synthesis. Trost, BM.; Fleming, I.; Paquette, LA., editors. Vol. 5. Oxford, UK: Pergamon Press; 1991. p. 1129-1162.(b) Grotjahn, DB. Comprehensive Organome-tallic Chemistry II. Abel, EW.; Stone, FGA.; Wilkinson, G.; Hegedus, L., editors. Vol. 12. Oxford, UK: Pergamon Press; 1995. p. 741-770.(c) Saito S, Yamamoto Y. Chem. Rev. 2000; 100:2901. [PubMed: 11749309] (d) Gevorgyan V, Radhakrishnan U, Takeda A, Rubina M, Rubin M, Yamamoto Y. J. Org. Chem. 2001; 66:2835. [PubMed: 11304209] (e) Yamamoto Y. Curr. Org. Chem. 2006; 9:503.(f) Gandon V, Aubert C, Malacria M. Chem. Commun. 2006; 21:2209.

3. Review: Kotha S, Brachmachary K, Lahiri K. Eur. J. Org. Chem. 2005:4741.Recent reports: Gandon V, Leca D, Aechter T, Vollhardt KPC, Malacria M, Aubert C. Org. Lett. 2004; 6:3405. 
[PubMed: 15355063] Kezuka S, Tanaka T, Ohe Y, Nakaya Y, Takeuchi R. J. Org. Chem. 2006; 71:543. [PubMed: 16408962] Shibata T, Fujimoto T, Yokota K, Takagi K. J. Am. Chem. Soc. 2004; 126:8382. [PubMed: 15237987] Takeuchi R, Nakaya Y. Org. Lett. 2003; 5:3659. [PubMed: 14507198] Novak P, Pohl R, Kotora M, Hocek M. Org. Lett. 2006; 8:2051. [PubMed: 16671779] Tanaka K, Sagae H, Toyoda K, Noguchi K, Hirano M. J. Am. Chem. Soc. 2007; 129:1522. [PubMed: 17283993]

4. Recent reports: Tanaka K, Wada A, Noguchi K. Org. Lett. 2005; 7:4737. [PubMed: 16209523] Duong HA, Cross MJ, Louie J. J. Am. Chem. Soc. 2004; 126:11438. [PubMed: 15366880] Yamamoto Y, Takagishi H, Itoh K. Org. Lett. 2001; 3:2117. [PubMed: 11418063] Yamamoto Y, Kinpara K, Saigoku T, Takagishi H, Okuda S, Nishiyama H, Itoh K. J. Am. Chem. Soc. 2005; 127:605. [PubMed: 15643884]

5. Review: Varela JA, Saa' C. Chem. Rev. 2003; 103:3787. [PubMed: 12964884] Recent reports: Bonaga LVR, Zhang HC, Moretto AF, Ye H, Gauthier DA, Li J, Leo GC, Maryanoff BE. J. Am. Chem. Soc. 2005; 127:3473. [PubMed: 15755167] Gutnov A, Heller B, Fischer C, Drexler HJ, Spannenberg A, Sunderman B, Sunderman C. Angew. Chem., Int. Ed. 2004; 43:3795. Yamamoto Y, Ogawa R, Itoh K. J. Am. Chem. Soc. 2001; 123:6189. [PubMed: 11414858] McCormick MM, Duong HA, Zuo G, Louie J. J. Am. Chem. Soc. 2005; 127:5030. [PubMed: 15810832]

6. (a) Tsuda T, Morikawa S, Saegusa T. J. Chem Soc., Chem. Commun. 1979:982.(b) Tsuda T, Morikawa S, Sumiya R, Saegusa T. J. Org. Chem. 1988; 53:3140.(c) Louie J, Gibby JE, Farnworth MV, Tekavec TN. J. Am. Chem. Soc. 2002; 124:15188. [PubMed: 12487590] (d) Tekavec TN, Arif AM, Louie J. Tetrahedron. 2004; 60:7431.

7. (a) Tsuda T, Kiyoi T, Miyane T, Saegusa T. J. Am. Chem. Soc. 1988; 110:8570.(b) Tekavec TN, Louie J. Org. Lett. 2005; 7:4037. [PubMed: 16119961]

8. Yamamoto Y, Takagishi H, Itoh K. J. Am. Chem. Soc. 2002; 124:6844. [PubMed: 12059203]

9. For stoichiometric examples with Co, see: Harvey DF, Johnson BM, Ung CS, Vollhardt KPC. Synlett. 1989:15-18. Gleiter R, Schehlmann V. Tetrahedron Lett. 1989; 30:2893.

10. (a) Mann G, Incarvito C, Rheingold AL, Hartwig JF. J. Am. Chem. Soc. 1999; 121:3224.(b) Mann G, Hartwig. J. Am. Chem. Soc. 1996; 118:13109.(c) Widenhoefer RA, Zhong HA, Buchwald SL. J. Am. Chem. Soc. 1997; 119:6787.(d) Widenhoefer RA, Buchwald SL. J. Am. Chem. Soc. 1998; 120:6504.

11. (a) Zhao J, Hesslink H, Hartwig JF. J. Am. Chem. Soc. 2001; 123:7220. [PubMed: 11472149] (b) Zhao P, Incarvito CD, Hartwig JF. J. Am. Chem. Soc. 2006; 128:3124. [PubMed: 16522075] (c) Ng SM, Zhao C, Lin Z. J. Organomet. Chem. 2002; 662:120.

12. Macgregor SA, Neave GW, Smith C. Faraday Discuss. 2003; 124:111. [PubMed: 14527213]

13. Masunaga PT, Hillhouse GL. J. Am. Chem. Soc. 1993; 115:2075. Koo K, Hillhouse GL. Organometallics. 1995; 14:456. Koo K, Hillhouse GL. Organometallics. 1996; 15:2669. Koo K, Hillhouse GL. Organometallics. 1998; 17:2924. Han R, Hillhouse GL. J. Am. Chem. Soc. 1997; 119:8135.C-N reductive elimination: Koo K, Hillhouse GL. Organometallics. 1995; 14:4421.

14. (a) Wolfe JP, Wagaw S, Buchwald SL. J. Am. Chem. Soc. 1996; 118:7215.(b) Driver SM, Hartwig JF. J. Am. Chem. Soc. 1996; 118:7217.(c) Palucki M, Wolfe JP, Buchwald SL. J. Am. Chem. Soc. 1997; 119:3395.(d) Yang BH, Buchwald SL. Org. Lett. 1999; 1:35. [PubMed: 10822529] (e) Torraca KE, Huang X, Parrish LA, Buchwald SL. J. Am. Chem. Soc. 2001; 123:10770. [PubMed: 11674023] (f) Kawatsura M, Hartwig JF. J. Am. Chem. Soc. 2000; 122:9546.(g) Harris MC, Huang X, Buchwald SL. Org. Lett. 2002; 4:2885. [PubMed: 12182580]

15. It $\mathrm{Bu}=1,3$-di-tert-butylimidazol-2-ylidene; IMes = 1,3-bis(2,4,6-trimethylphenyl)imidazol-2ylidene; $\operatorname{IPr}=1,3$-bis(2,6-diisopropylphenyl)-imidazol-2-ylidene; $\operatorname{SIPr}=1,3$-bis(2,6diisopropylphenyl)-4,5-dihydroim-idazolin-2-ylidene.

16. (a) Zuo G, Louie J. Angew. Chem. Int. Ed. 2004; 43:2277.(b) Zuo G, Louie J. J. Am. Chem. Soc. 2005; 127:5798. [PubMed: 15839672]

17. The thermal electrocyclic ring opening of fused a-pyrans is common, see: Marvell EN, Caple G, Gosink TA, Zimmer G. J. Am. Chem. Soc. 1966; 88:619. Marvell EN, Chadwick T, Caple G, Gosink T, Zimmer G. J. Org. Chem. 1972; 37:2992. Kluge AF, Lillya CP. J. Org. Chem. 1971; 36:1979. Trost BM, Rudd MT, Costa MG, Lee PI, Pomerantz AE. Org. Lett. 2004; 6:4235. [PubMed: 15524451]

18. Some of this work has been previously reported, see ref $7 \mathrm{~b}$. 
19. In some cases, excess aldehyde was necessary due to competitive NHC-catalyzed aldehyde cyclotrimerization.

20. (a) Takimoto M, Mizuno T, Mori M, Sato Y. Tetrahedron. 2006; 62:7589.(b) Takimoto M, Mizuno T, Sato Y, Mori M. Tetrahedron Lett. 2005; 46:5173.

21. (a) Yu RT, Rovis T. J. Am. Chem. Soc. 2006; 128:12370. [PubMed: 16984159] (b) Yu RT, Rovis T. J. Am. Chem. Soc. 2006; 128:2782. [PubMed: 16506740]

22. The diastereoselectivity of pyran $\mathbf{3 7}$ could not be determined by NMR analysis due to the conformation of the ring; pyran $\mathbf{3 7}$ possesses a particularly flattened out structure due to the olefin and lacks any 1,3 interations in the NOE analysis. Unfortunately, we were unable to grow suitable crystals for X-ray analysis to determine the structure of pyran 37.

23. See the Supporting Information for complete X-ray analysis.

24. (a) Ho C-Y, Jamison TF. Angew. Chem., Int. Ed. 2007; 46:782.(b) Ho C-Y, Jamison TF. J. Am. Chem. Soc. 2006; 128:5362. [PubMed: 16620106] (c) Ng S-S, Ho C-Y, Jamison TF. J. Am. Chem. Soc. 2006; 128:11513. [PubMed: 16939275] (d) Miller KM, Jamison TF. Org. Lett. 2005; 7:3077. [PubMed: 15987209] (e) Miller KM, Jamison TF. J. Am. Chem. Soc. 2004; 126:15342. [PubMed: 15563136] (f) Miller KM, Luanphaisarnnont T, Molinaro C, Jamison TF. J. Am. Chem. Soc. 2004; 126:4130. [PubMed: 15053602] (g) Huang W-S, Chan J, Jamison TF. Org. Lett. 2000; 2:4221. [PubMed: 11150204] (h) Miller KM, Huang W-S, Jamison TF. J. Am. Chem. Soc. 2003; 125:3442. [PubMed: 12643701] (i) Miller KM, Molinaro C, Jamison TF. Tetrahedron: Asymmetry. 2003; 14:3619.

25. (a) Sa-ei K, Montgomery J. Org. Lett. 2006; 8:4441. [PubMed: 16986920] (b) Montgomery J. Angew. Chem., Int. Ed. 2004; 43:3890.(c) Mahandru GM, Liu G, Montgomery J. J. Am. Chem. Soc. 2004; 126:3698. [PubMed: 15038707] (d) Ni Y, Amarasinghe KD, Montgomery J. Org. Lett. 2002; 4:1743. [PubMed: 12000288]

26. (a) Ogoshi S, Ueta M, Arai T, Kurosawa H. J. Am. Chem. Soc. 2005; 127:12810. [PubMed: 16159269] (b) Ogoshi S, Oka M, Kurosawa H. J. Am. Chem. Soc. 2004; 126:11802. [PubMed: 15382909]

27. Trost has utilized acetone as a solvent in Ru-catalyzed cycloisomerizations of diynes and does not report any reactivity with the acetone, see ref $17 \mathrm{~d}$.

28. Without the addition of $3 \AA$ molecular sieves, cyclization reactions gave inconsistent isolated yields of dihydropyran, and yields ranged from $70 \%$ to $83 \%$.

29. (a) Saito A, Oka Y, Nozawa Y, Hanzawa Y. Tetrahedron Lett. 2006; 47:2201.(b) Ikeda S, Miyashita H, Taniguchi M, Kondo H, Okano M, Sato Y, Odashima K. J. Am. Chem. Soc. 2002; 124:12060. [PubMed: 12371822]

30. Carmona E, Gutierrez-Puebla E, Mar'nn JM, Monge A, Paneque M, Poveda ML, Ruiz C. J. Am. Chem. Soc. 1989; 111:2883. 


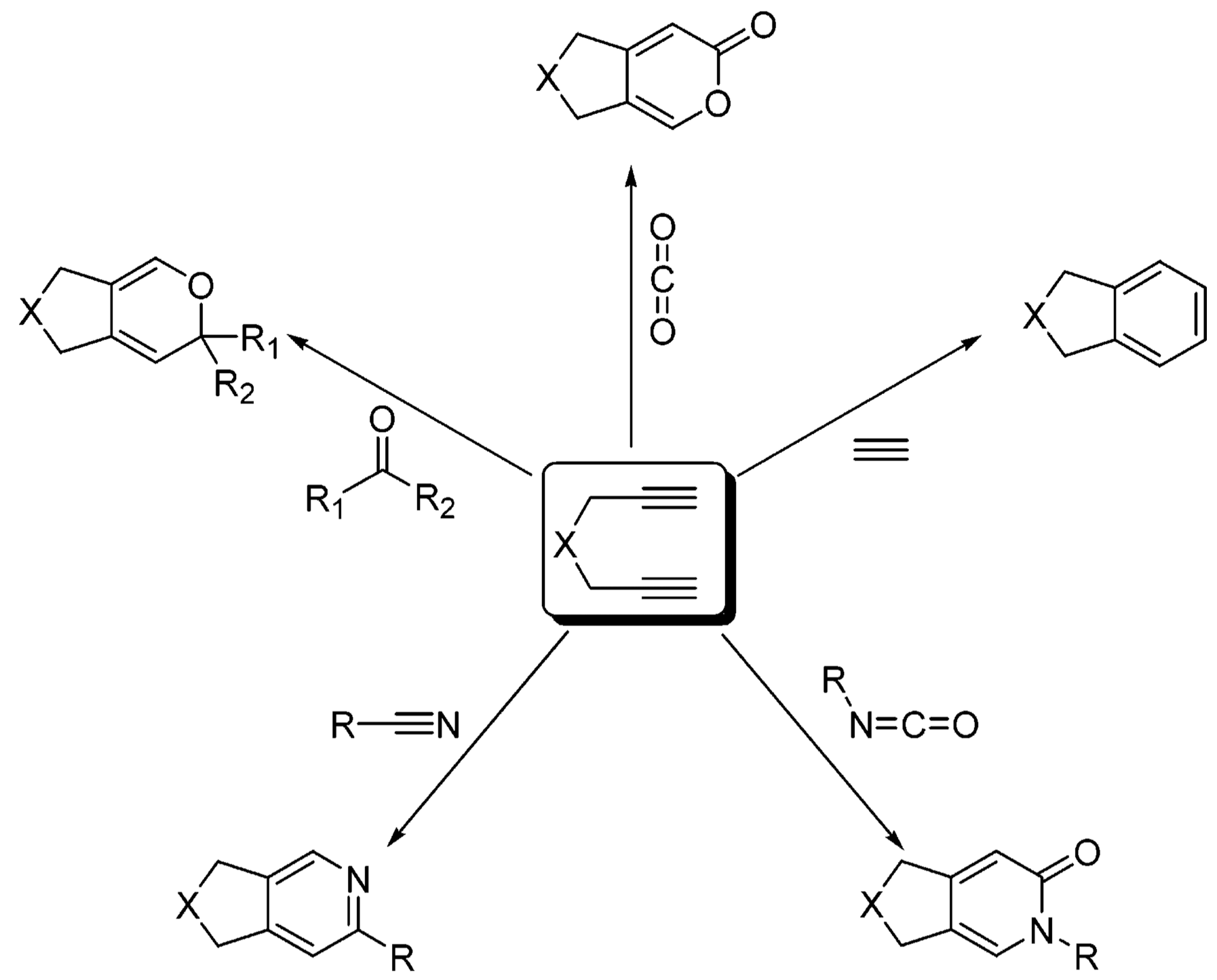

SCHEME 1.

$[2+2+2]$ Cycloaddition of Diynes with Various Electrophiles 
<smiles>[R7]C#CCCCCC#C[R]</smiles>

Tsuda, 1988

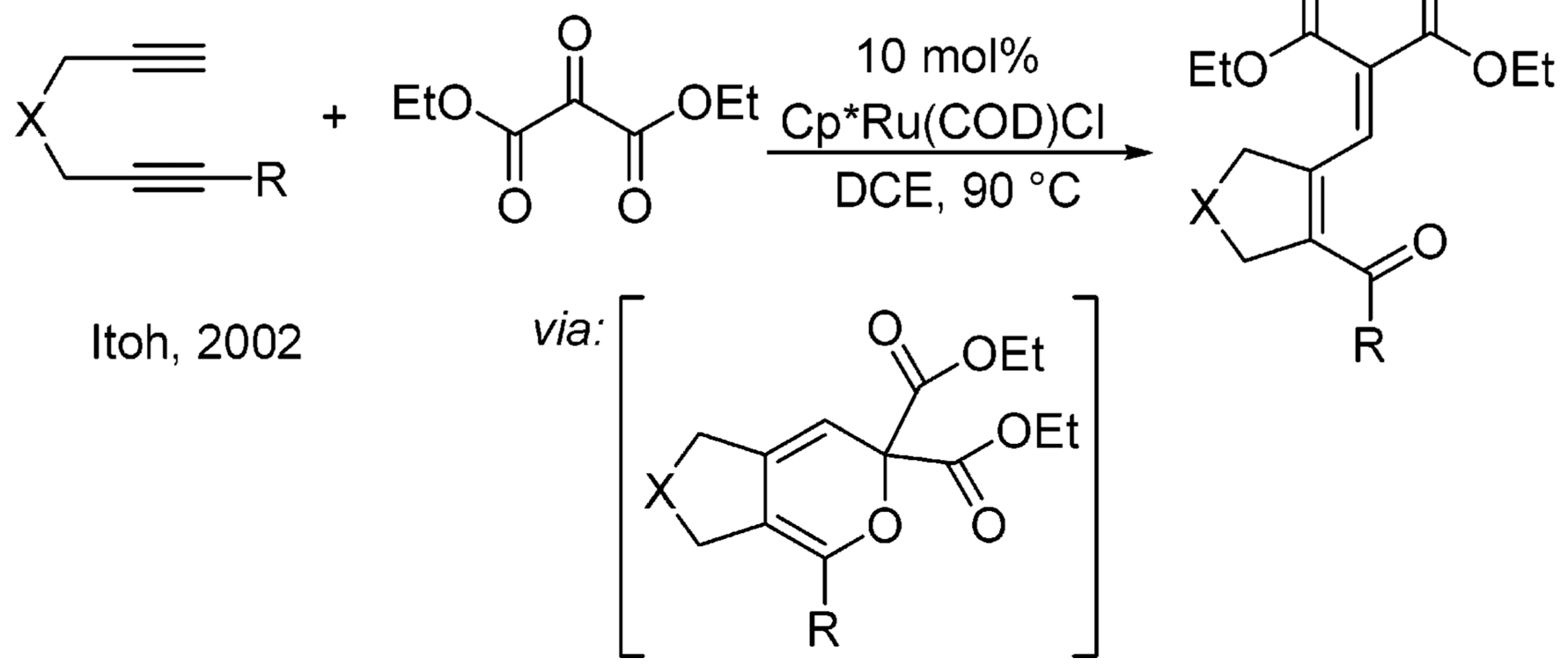

SCHEME 2.

Previous Cycloadditions of Diynes and Carbonyls 


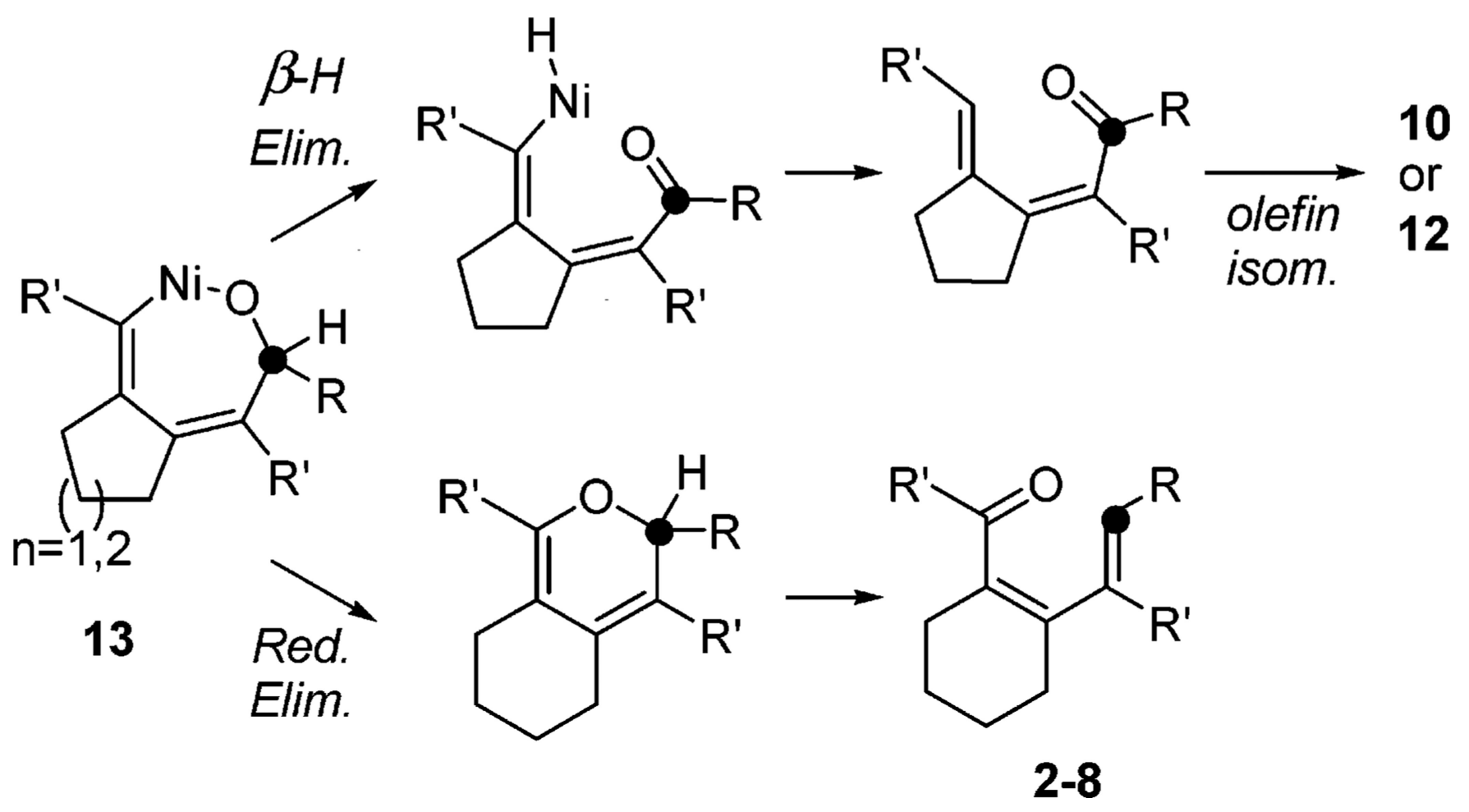

SCHEME 3.

Mechanistic Explanation for a Products Dichotomy in the Cycloaddition of Diynes of Varying Length 
<smiles>[R]C(=O)C([R])=C1CCCC(C)C1C(C)(C)C</smiles>
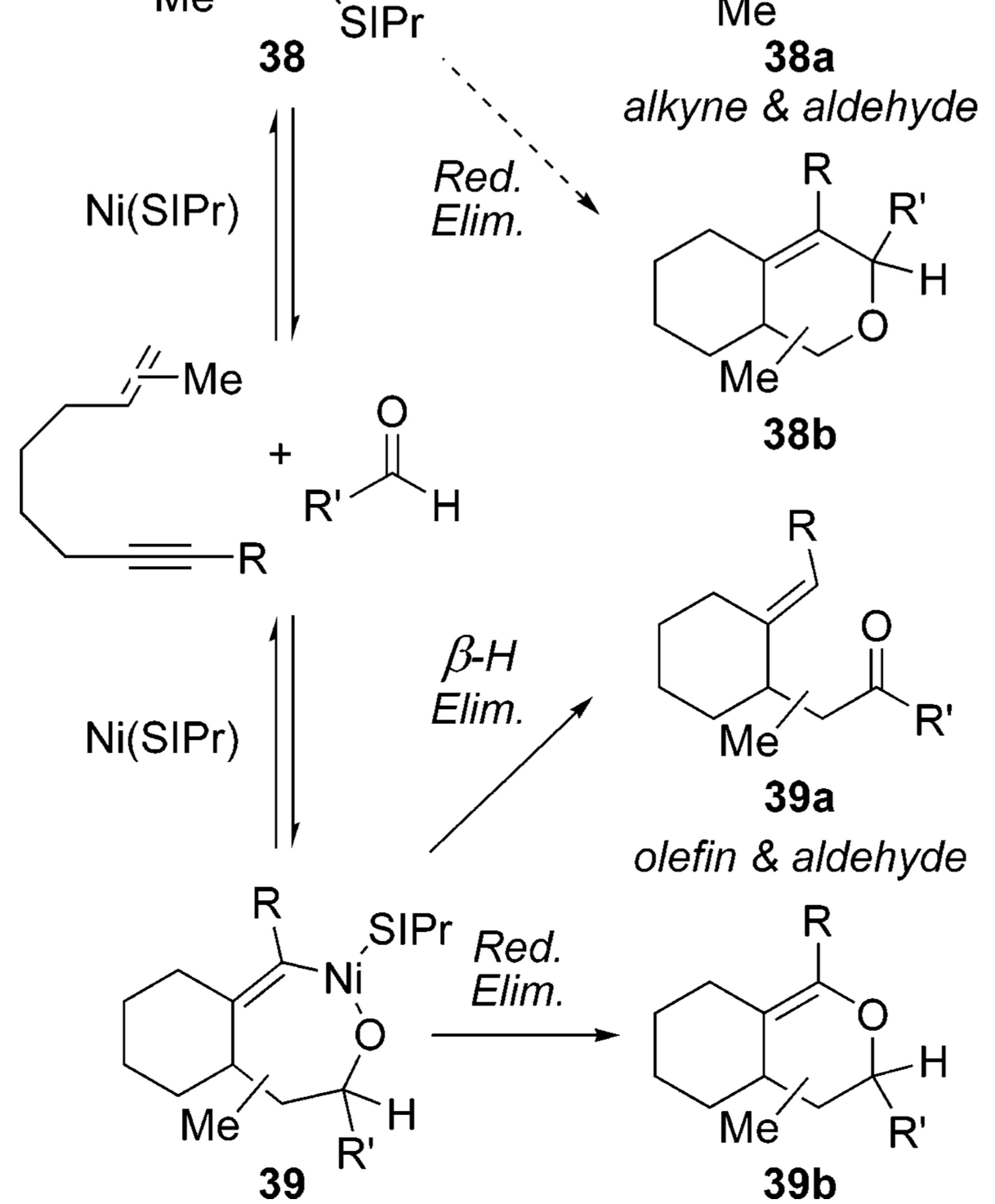<smiles>[R]C1=C2CCCCC2C([R])([R3])CC([R])O1</smiles>

SCHEME 4.

Proposed Mechanism for the Cycloaddition of Enynes and Aldehydes 


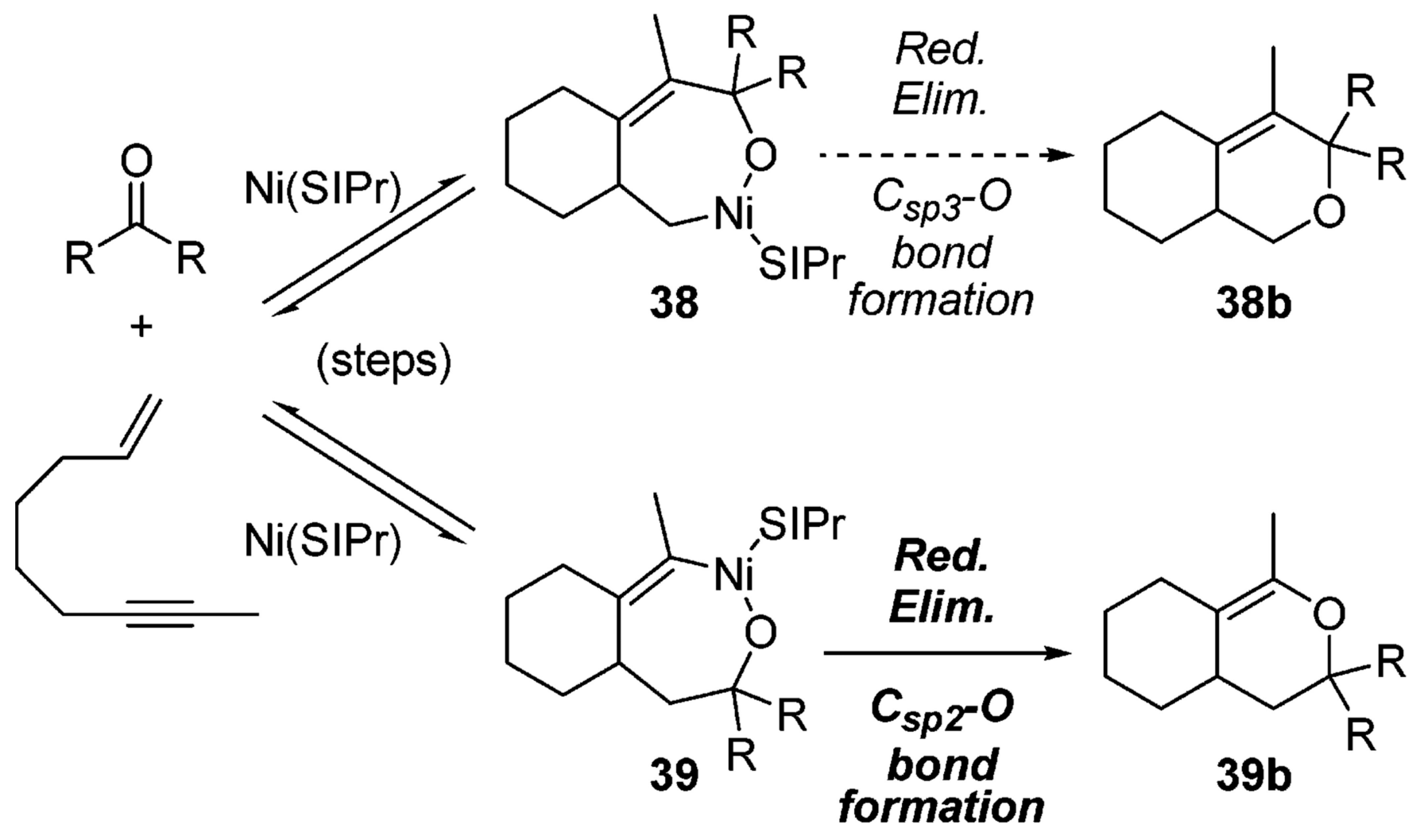

SCHEME 5.

Cycloaddition of Enynes and Ketones 


\section{TABLE 1}

Evaluation of Ligands in the Ni-Catalyzed Cycloadditions of Diyne 1 and Benzaldehyde ${ }^{a}$

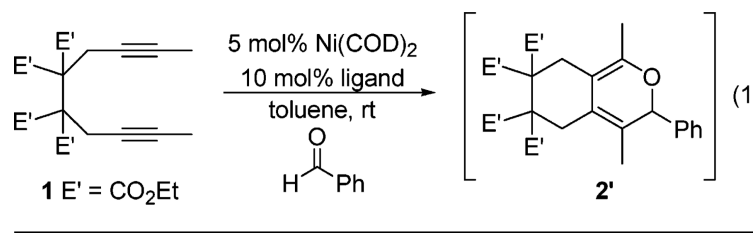

\begin{tabular}{|c|c|c|c|}
\hline Entry & ligand & conversion $(\%)^{b}$ & yield $(\%)^{l}$ \\
\hline 1 & none & 0 & 0 \\
\hline 2 & $\mathrm{PPh}_{3}$ & 6 & 0 \\
\hline 3 & $\mathrm{PCy}_{3}$ & 0 & 0 \\
\hline 4 & dppf & 0 & 0 \\
\hline 5 & $( \pm)$ BINAP & 0 & 0 \\
\hline 6 & & 8 & 0 \\
\hline 7 & & 0 & 0 \\
\hline 8 & $\mathrm{I}^{t} \mathrm{Bu}$ & 95 & 8 \\
\hline 9 & IMes & 23 & 23 \\
\hline 10 & $\operatorname{IPr}$ & 87 & 56 \\
\hline 11 & SIPr & 98 & 80 \\
\hline
\end{tabular}

${ }^{a}$ Reaction conditions: $0.1 \mathrm{M}$ diyne 1, $0.125 \mathrm{M} \mathrm{PhCHO}, 5 \mathrm{~mol} \% \mathrm{Ni(COD)} 2,10 \mathrm{~mol} \%$ ligand, toluene, room temperature.

$b$ Determined by GC based on napthalene as the internal standard. 
TABLE 2

Ni-Catalyzed Cycloadditions with a Variety of Aldehydes ${ }^{a}$

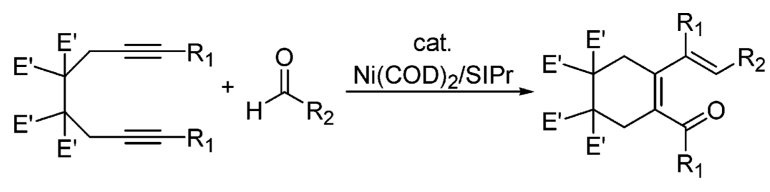

\begin{tabular}{cllcl}
\hline Entry & diyne & aldehyde & $\begin{array}{c}\text { dienone } \\
\text { product }\end{array}$ & $\begin{array}{c}\text { yield } \\
(\%)\end{array}$ \\
\hline 1 & $\mathbf{1}\left(\mathrm{R}_{1}=\mathrm{Me}\right)$ & $\mathrm{R}_{2}=\mathrm{C}_{6} \mathrm{H}_{5}$ & $\mathbf{2}$ & 78 \\
2 & $\mathbf{1}$ & $\mathrm{R}_{2}=4-\mathrm{MeO}-\mathrm{C}_{6} \mathrm{H}_{4}$ & $\mathbf{3}$ & 91 \\
3 & $\mathbf{1}$ & $\mathrm{R}_{2}=4-\mathrm{CF}_{3}-\mathrm{C}_{6} \mathrm{H}_{4}$ & $\mathbf{4}$ & $65^{c}$ \\
4 & $\mathbf{1}$ & $\mathrm{R}_{2}=i-\mathrm{Pr}$ & $\mathbf{5}$ & $58^{d e}$ \\
5 & $\mathbf{1}$ & $\mathrm{R}_{2}=n-\mathrm{Pr}$ & $\mathbf{6}$ & $72^{d e}$ \\
6 & $\mathbf{7}\left(\mathrm{R}_{1}=\mathrm{Et}\right)$ & $\mathrm{R}_{2}=\mathrm{C}_{6} \mathrm{H}_{5}$ & $\mathbf{8}$ & 80 \\
\hline
\end{tabular}

\footnotetext{
${ }^{a}$ Reaction conditions: $0.1 \mathrm{M}$ diyne, $0.125 \mathrm{M}$ aldehyde, $5 \mathrm{~mol} \% \mathrm{Ni}(\mathrm{COD}) 2,10 \mathrm{~mol} \% \mathrm{SIPr}$, room temperature.

$b_{\text {Isolated yields (average of two runs). }}$

$c_{10 \mathrm{~mol} \% \mathrm{Ni}(\mathrm{COD}) 2,20 \mathrm{~mol} \% \mathrm{SIPr} .}$

$d_{10 \mathrm{~mol} \% \mathrm{Ni}(\mathrm{COD}) 2}, 10 \mathrm{~mol} \% \mathrm{SIPr}$.

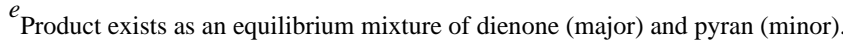




\section{TABLE 3}

Ni-Catalyzed Cycloadditions of Enynes and Aldehydes ${ }^{a}$

entry

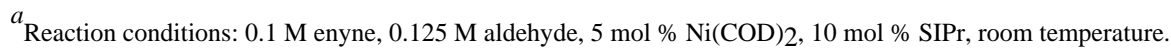

$b_{\text {Isolated yields (average of two runs). }}$

${ }^{c} 7.5 \mathrm{~mol} \% \mathrm{Ni}(\mathrm{COD}) 2,15 \mathrm{~mol} \% \mathrm{SIPr}$.
} 


\section{TABLE 4}

Ni-Catalyzed Cycloadditions of Enynes with Varying Alkyne Substituents ${ }^{a}$

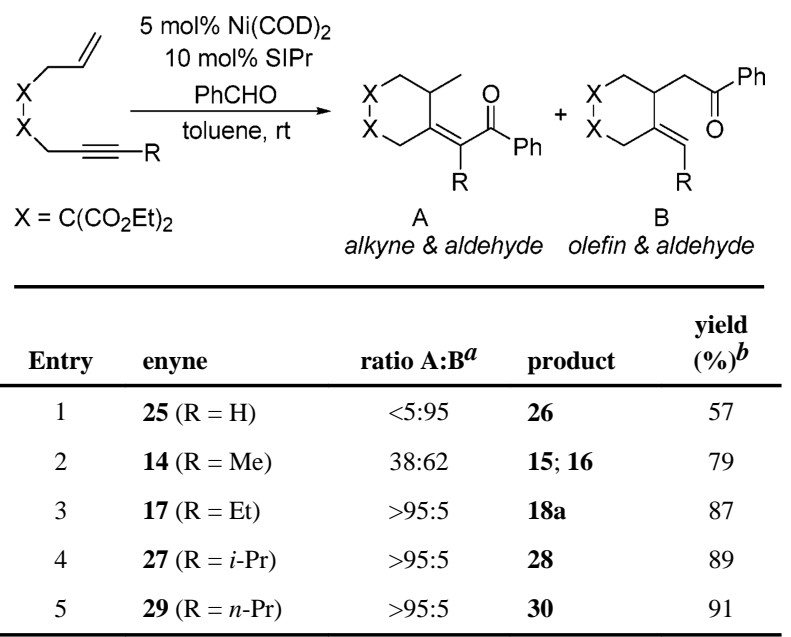

${ }^{a}$ Determined by ${ }^{1} \mathrm{H}$ NMR analysis of crude reaction mixture.

$b_{\text {Isolated yield, average of two runs. }}$ 


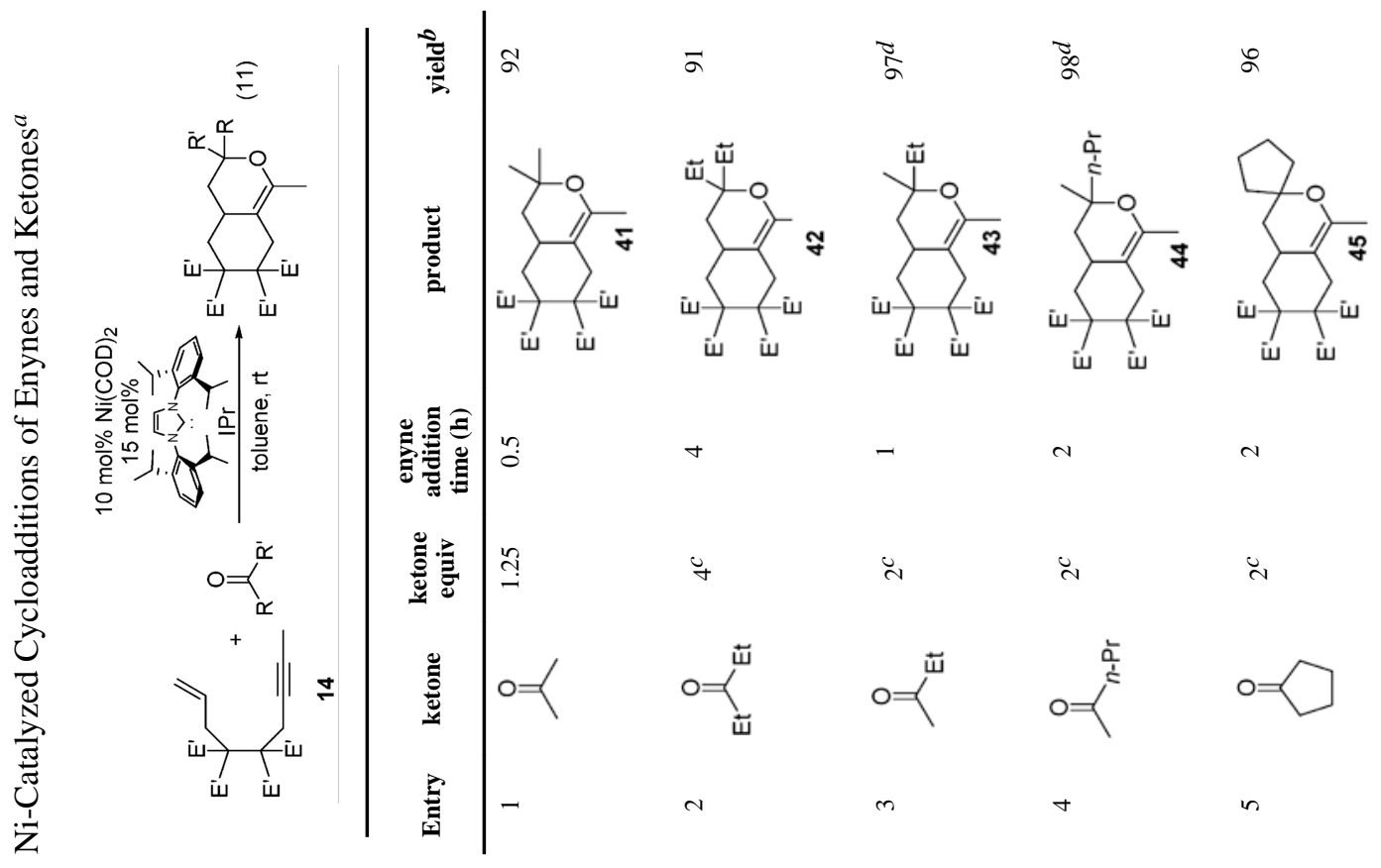




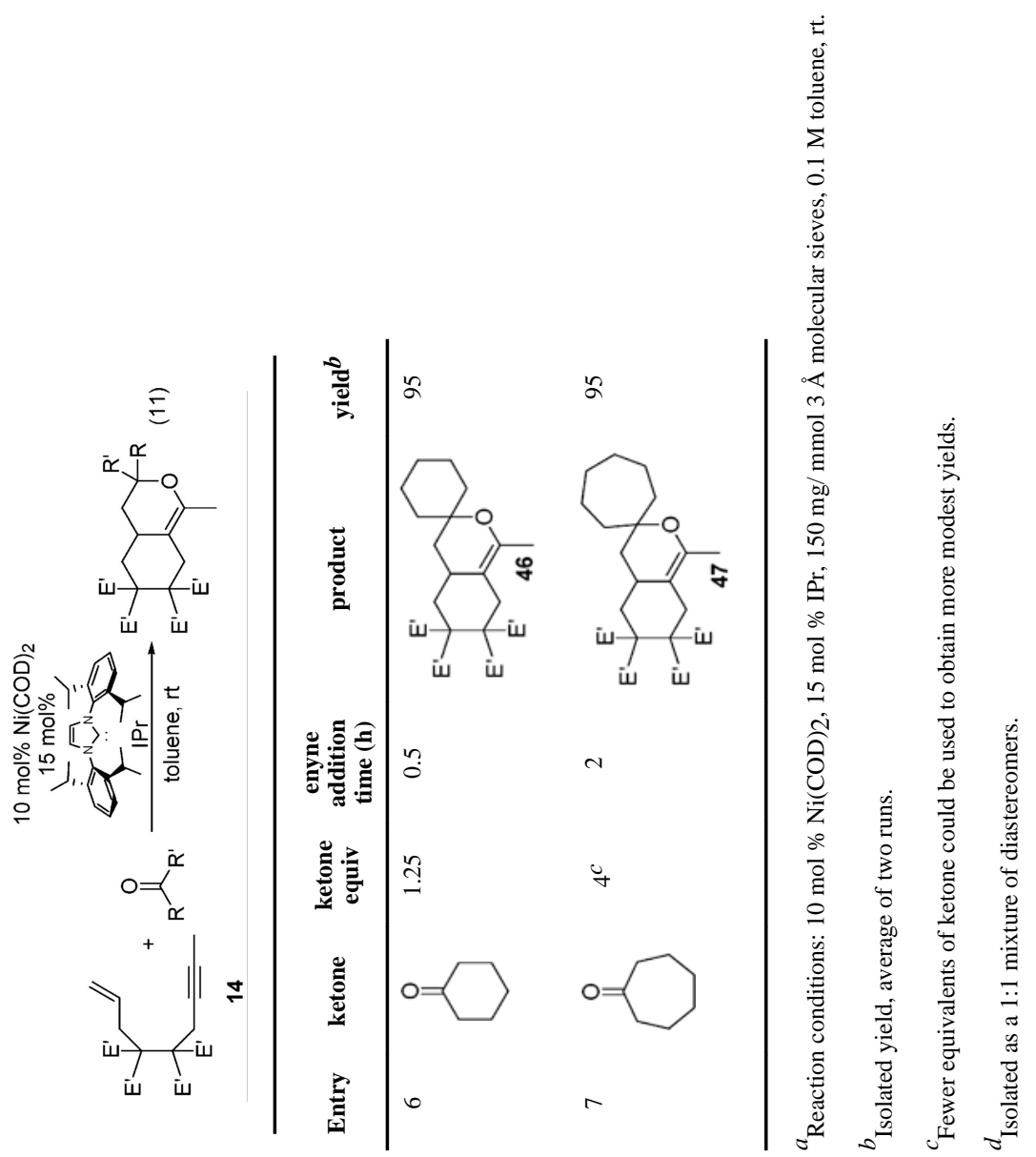




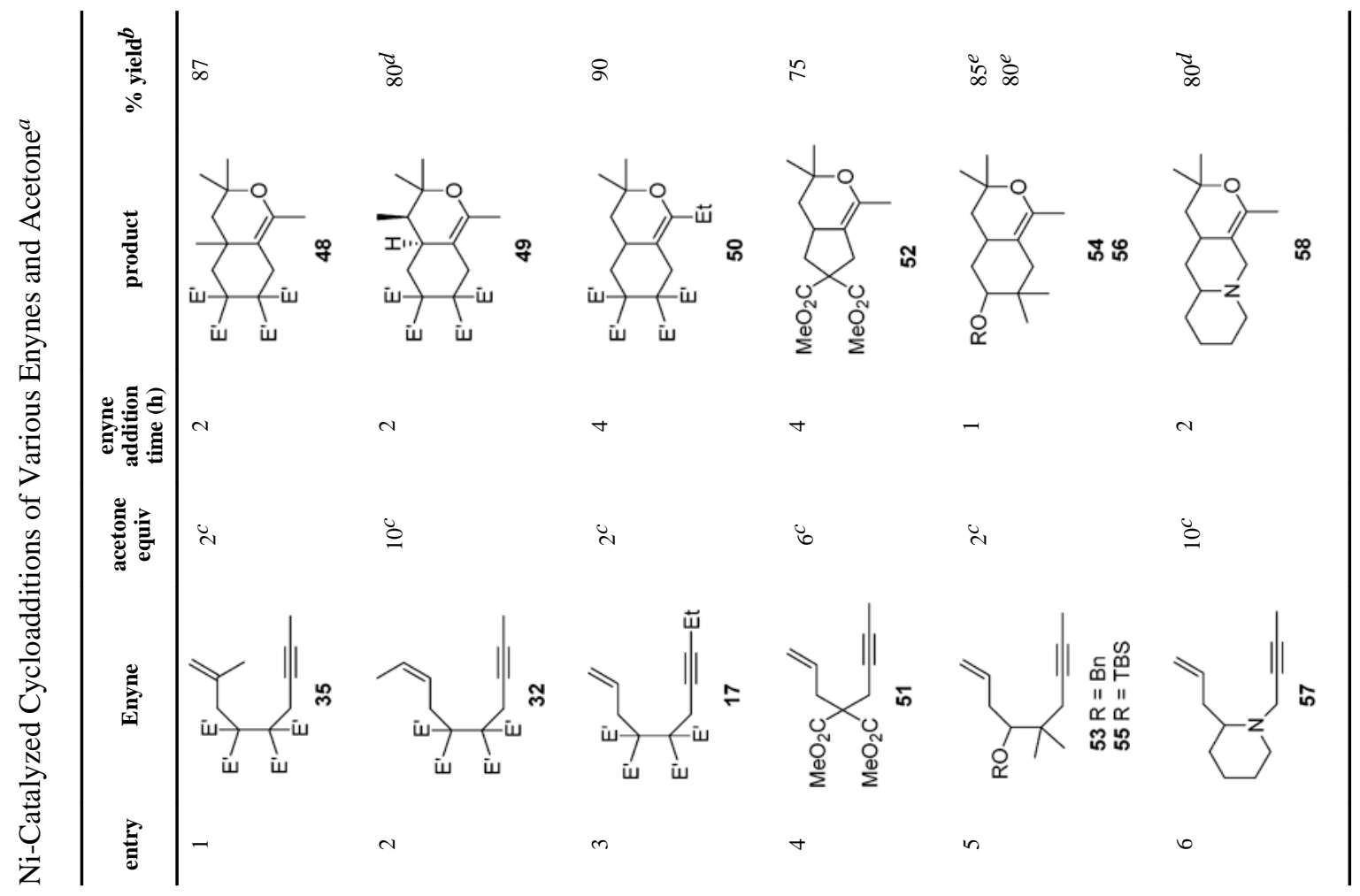




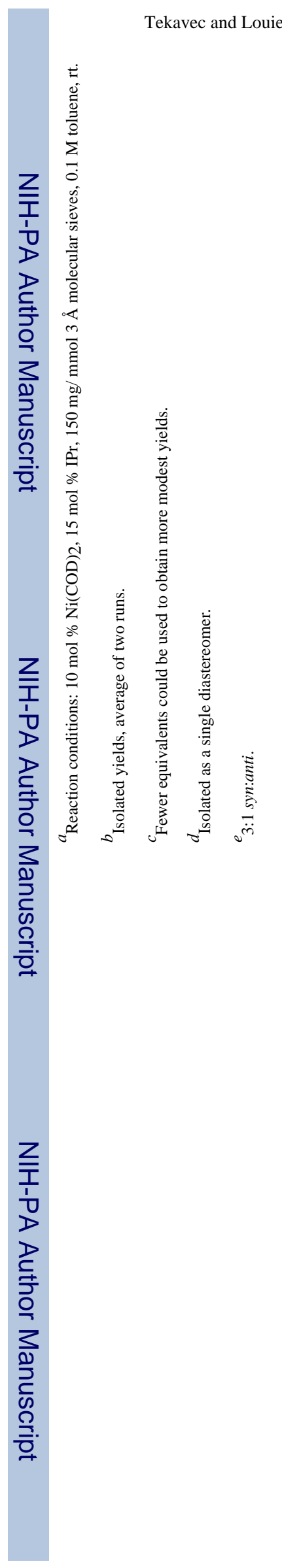

Page 26

J Org Chem. Author manuscript; available in PMC 2014 August 26. 